\title{
SIKAP DAN PERSEPSI KONSUMEN TERHADAP JERUK LOKAL DAN JERUK IMPOR DI PASAR MODERN KOTA BOGOR
}

\author{
Sarah Nur Nafisah ${ }^{1)}$, Suharno ${ }^{2)}$ dan Netti Tinaprilla ${ }^{3)}$ \\ ${ }^{1,2,3)}$ Departemen Agribisnis, Fakultas Ekonomi dan Manajemen,Institut Pertanian Bogor \\ ${ }^{1)}$ sarahnafisah1892@yahoo.com
}

\begin{abstract}
The trends within citrus consumption have shifted from consumption of local citrus to the imported citrus. The present research investigates th econsumer characteristics of citrus, the consumer purchasing decision process, and consumer attitude and perception towards local citruss and imported citruss. Adopting purposive sampling technique, 100 respondents were chosen among the population of citrus consumers in modern market in Bogor. The data was analyzed with descriptive analysis, multi attribute Fishbein model, and perceptual mapping. The results showed that the majority of consumers were productive age female ranging from 27 to 34 years, married, bachelor degree, housewife with 3-4 family members, and with more than Rp 4.000.000 income per month. For both citrus, taste and freshness are the most important attributes Local citrus's attributes such as taste, size, juicy, availability, appearance, freshness, the level of maturity, and the texture of pulp, were believed as a good attribute. Meanwhile for imported citrus, the juicyness, appearance, freshness, the level of maturity, the texture of pulp,andthesalespromotion, were believedto be agoodattribute. The price of bothlocal citrus and imported citruswas not believed as a good attribute. The score of consumer attitude and perception toward local citrus were higher than that of imported citrus. This shows that generally the local citrus' attribute in modern market Bogor City was perceived as good by the consumers. Due to that the local citrus agribusiness actors needs to maintain and improve the performance of local citrus'attribute in such a way that the consumer prefer local citrus than imported citrus.
\end{abstract}

Keyword(s): citrus, consumer, attitude, perception, multi attribute Fishbein model.

\begin{abstract}
ABSTRAK
Tren dalam konsumsi buah jeruk telah bergeser dari konsumsi buah jeruk lokal ke konsumsi buah jeruk impor. Penelitian ini bertujuan mengidentifikasi karakteristik umum konsumen buah jeruk, menganalisis proses keputusan pembelian konsumen terhadap buah jeruk, serta menganalisis sikap dan persepsi konsumen terhadap buah jeruk lokal dan buah jeruk impor. Sebanyak 100 responden dipilih secara sengaja dari populasi konsumen buah jeruk di pasar modern Kota Bogor. Metode analisis data yang digunakan adalah analisis deskriptif, model multi atribut Fishbein dan pemetaan persepsi. Hasil penelitian menunjukkan bahwa mayoritas konsumen adalah perempuan dengan usia produktif 27-34 tahun, berstatus menikah, berpendidikan sarjana, bekerja sebagai ibu rumah tangga, memiliki anggota keluarga 3-4 orang, dan pendapatan setiap bulan di atas Rp 4.000.000. Rasa dan kondisi kesegaran merupakan atribut buah jeruk yang sangat penting bagi konsumen. Atribut jeruk lokal seperti rasa, ukuran, kandungan air, ketersediaan, penampilan (kebersihan kulit dan warna kulit), kondisi kesegaran, tingkat kematangan, dan tekstur daging buah dipercaya sebagai atribut yang baik. Kandungan air, penampilan (kebersihan kulit dan warna kulit), kondisi kesegaran, tingkat kematangan, tekstur daging buah, dan promosi penjualan dipercaya sebagai atribut jeruk impor yang baik. Sedangkan atribut harga pada jeruk lokal dan jeruk impor belum mendapatkan kepercayaan yang
\end{abstract}


baik. Sikap dan persepsi konsumen terhadap jeruk lokal memiliki nilai yang lebih tinggi dibandingkan sikap dan persepsi konsumen terhadap jeruk impor. Hal ini menunjukkan bahwa secara umum atribut jeruk lokal yang dijumpai konsumen di pasar modern Kota Bogor sudah baik sehingga pelaku agribisnis jeruk lokal perlu mempertahankan dan meningkatkan kinerja atributnya agar konsumen lebih memilih untuk mengkonsumsi jeruk lokal.

Kata Kunci: jeruk, konsumen, sikap, persepsi, model multi atribut Fishbein

\section{PENDAHULUAN}

Buah jeruk merupakan salah satu buah yang memiliki konsumsi tertinggi dibandingkan dengan buah lainnya seperti buah pisang, pepaya, rambutan, dan apel dilihat dari konsumsi rata-rata per kapita seminggu menurut jenis makanan dan golongan pengeluaran sebulan tahun 2009 (SUSENAS 2009). Produksi buah jeruk siam di Indonesia tahun 2008-2012 mengalami pertumbuhan yang negatif yaitu sebesar $-12.99 \%$ (Direktorat Jenderal Hortikultura 2013). Permintaan masyarakat terhadap buah jeruk akan meningkat seiring dengan meningkatnya pendapatan dan jumlah penduduk. Konsumsi masyarakat terhadap buah jeruk yang mengalami peningkatan tidak diikuti dengan kenaikan produksi dalam negeri namun diikuti dengan meningkatnya impor buah jeruk.

Nilai impor buah jeruk pada tahun 2012 yaitu sebesar US\$ 227.300.473 (Direktorat Jenderal Hortikultura 2013) dan volume impor buah jeruk tahun 2012 yaitu sebesar 258.446.354 kg dengan rata-rata pertumbuhan sebesar $8.81 \%$ (Kementrian Pertanian 2013). Hal ini menunjukkan terjadinya pergeseran konsumsi dari buah jeruk lokal menjadi buah jeruk impor dikarenakan jeruk lokal belum dapat menunjukkan keunggulan- nya dari segi kualitas, kuantitas, dan kontinuitas. Oleh karena itu, buah jeruk lokal harus memiliki keunggulan agar dapat memenangkan persaingan dengan jeruk impor di pasar dalam negeri.

Persaingan antara jeruk lokal dengan jeruk impor terdapat di berbagai tempat penjualan, mulai dari pasar swalayan, pasar tradisional, dan kios-kios buah sehingga konsumen dihadapkan pada berbagai pilihan dalam membeli buah jeruk. Keberadaan pasar modern memberikan suatu alternatif bagi konsumen untuk memperoleh buah jeruk dengan kualitas yang lebih baik, kemasan buah yang lebih rapi, serta kenyamanan dalam berbelanja (Kartika et. al. 2010).

Kota Bogor merupakan salah satu kota besar di provinsi Jawa Barat dengan kepadatan penduduk yang cenderung meningkat. Pada tahun 2000, jumlah penduduk di Kota Bogor sebesar 750.819 jiwa dan mengalami laju pertumbuhan penduduk per tahun sebesar $2.38 \%$ hingga tahun 2010 jumlah penduduk Kota Bogor menjadi 950.334 jiwa. Kota Bogor juga memiliki pertumbuhan ekonomi dan pengeluaran rata-rata per kapita per bulan untuk buah-buahan yang cenderung meningkat setiap tahunnya (BPS Kota Bogor 2012). Hal ini menunjukkan bahwa Kota Bogor merupakan salah satu daerah tujuan pemasaran buah yang 
potensial. Peningkatan jumlah pasar modern di Kota Bogor menunjukkan bahwa pasar modern semakin berperan dalam memenuhi kebutuhan hidup masyarakat termasuk buah-buahan.

Konsumen merupakan salah satu komponen penting dalam sistem agribisnis. Memahami perilaku konsumen merupakan informasi pasar yang penting bagi sektor agribisnis sebagai bahan masukan untuk merencanakan, mengembangkan produk, dan memasarkan dengan lebih baik. Konsumen akan memilih produk yang mutunya lebih baik dengan harga yang lebih murah (Sumarwan 2004). Konsumen cenderung membeli buah-buahan yang berkualitas baik, namun tidak menilai bahwa buahbuahan impor selalu berkualitas baik sehingga konsumen bersikap netral terhadap buah-buahan impor. Dengan demikian buah dengan label impor tidak menjadikan konsumen bersikap lebih positif, tetapi penilaian konsumen terhadap buah yang menentukan sikap konsumen (Widodo 2005).

Sikap merupakan komponen penting dalam perilaku pembelian. Studi tentang sikap merupakan kunci untuk memahami perilaku pembelian. Sikap merupakan hasil evaluasi yang mencerminkan rasa suka atau tidak suka terhadap produk, sehingga pemasar dapat menduga potensi pembelian dan menyusun strategi pemasaran yang lebih efektif (Rangkuti 2003).

Dalam upaya untuk meningkatkan dan mempertahankan konsumen, perlu untuk mengetahui karakteristik konsumen dan proses keputusan pembelian konsumen terhadap buah jeruk. Proses keputusan pembelian konsumen memiliki lima tahap sebagaimana yang dikemukakan oleh Engel et al. (1995) yaitu tahap pengenalan kebutuhan, pencarian informasi, evaluasi alternatif, proses pembelian, dan perilaku pasca pembelian.

Faktor psikologis sangat berpengaruh dalam proses keputusan pembelian konsumen. Menurut Kotler dan Armstrong (2008) pilihan pembelian seseorang dipengaruhi oleh empat faktor psikologis utama yaitu motivasi, pembelajaran, sikap dan persepsi.

Permasalahan yang muncul kemudian adalah bagaimana karakteristik umum konsumen buah jeruk di pasar modern Kota Bogor? Bagaimana proses keputusan pembelian buah jeruk di pasar modern Kota Bogor? Bagaimana sikap dan persepsi konsumen terhadap jeruk lokal dan jeruk impor di pasar modern Kota Bogor? Dengan demikian, maka penelitian mengenai sikap dan persepsi konsumen terhadap jeruk lokal dan jeruk impor penting untuk membantu petani mengenali karakteristik buah jeruk yang diinginkan konsumen.

Penelitian ini bertujuan untuk mengkaji karakteristik umum konsumen buah jeruk di pasar modern Kota Bogor, mengidentifikasi proses keputusan pembelian konsumen terhadap buah jeruk di pasar modern Kota Bogor, mengkaji sikap dan persepsi konsumen terhadap buah jeruk lokal dan buah jeruk impor di pasar modern Kota Bogor melalui penilaian komponen evaluasi dan kepercayaan sehingga dapat menghasilkan implikasi dalam peningkatan sikap konsumen terhadap buah jeruk lokal. 


\section{METODE PENELITIAN}

\section{Lokasi dan Waktu Penelitian}

Penelitian ini dilakukan di dua pasar modern yang berada di Kota Bogor, yaitu Giant Botani Square dan Foodmart Plaza Ekalokasari pada bulan Maret hingga April 2013. Pemilihan Kota Bogor dan pasar modern (Giant Botani Square dan Foodmart Ekalokasari Plaza) dilakukan secara purposive. Desain yang digunakan dalam penelitian ini yaitu cross-sectional study.

\section{Metode Pengambilan Sampel}

Responden yang disertakan dalam penelitian ini berjumlah 100 orang. Metode pengambilan sampel dalam penelitin ini adalah non probability sampling dengan teknik purposive sampling. Responden yang dipilih adalah responden dengan usia diatas 17 tahun, dalam dua bulan terakhir mengkonsumsi buah jeruk lokal dan impor serta membelinya di pasar modern (Giant Botani Square dan Foodmart Ekalokasari Plaza).

\section{Jenis Data, Cara Pengumpulan Data, dan Pengukuran}

Data yang digunakan berupa data primer dan sekunder yang bersifat kuantitatif maupun kualitatif. Data primer diperoleh dari hasil wawancara responden dengan menggunakan kuesioner yaitu data karakteristik konsumen buah jeruk, proses keputusan pembelian konsumen buah jeruk, serta sikap dan persepsi konsumen terhadap buah jeruk lokal dan buah jeruk impor di pasar modern Kota Bogor.

Skala likert merupakan skala pengukuran ordinal dimana skala ini mengurutkan data dari tingkat yang paling rendah ke tingkat yang paling tinggi atau sebaliknya dengan interval yang tidak harus sama. Skala Likert menggunakan skor tertentu untuk setiap jawaban (Rangkuti 2005).

Tingkat kepentingan pada penelitian ini dilakukan dengan menggunakan skala likert lima angka yaitu sangat penting (5), penting (4), biasa saja (3), tidak penting (2) dan sangat tidak penting (1).

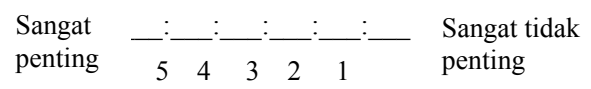

Tingkat kepercayaan pada penelitian ini juga diukur dengan menggunakan skala likert lima angka yaitu sangat baik (5), baik (4), biasa saja (3), buruk (2), dan sangat buruk (1).

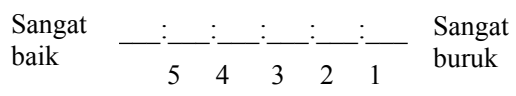

\section{Metode Pengolahan dan Analisis Data}

Metode pengolahan dan analisis data yang digunakan dalam penelitian ini adalah analisis kualitatif dan kuantitatif. Analisis kualitatif dilakukan secara deskriptif untuk menggambarkan karakteristik konsumen dan proses keputusan pembelian konsumen.

Sikap konsumen terhadap buah jeruk ditentukan oleh sikap konsumen terhadap atribut buah jeruk. Multiatribut buah dapat dilihat berdasarkan kriteria mutu produk buah seperti yang dikemukakan oleh Poerwanto et al. (2002) meliputi mutu visual atau penampakan, mouthfeel (rasa di mulut), nilai gizi dan zat yang berkhasiat (mutu fungsional), keamanaan konsumsi, kemudahan penanganan, dan sifat mutu lainnya. Berdasarkan kriteria 
mutu di atas, maka dapat dirumuskan sikap kepercayaan konsumen dalam memilih atribut buah yang dikehendaki konsumen.

Atribut buah jeruk yang digunakan dalam penelitian ini terdiri dari harga, rasa, kemudahan memperoleh, kandungan air, ukuran, warna kulit, kebersihan kulit, kondisi kesegaran, tingkat kematangan, tekstur daging buah, jumlah biji, dan promosi penjualan.

Penelitian ini menggunakan korelasi Pearson untuk uji validitas atribut dan untuk uji reliabilitas digunakan Cronbach's Alpha. Seluruh atribut yang digunakan dalam penelitian ini adalah valid dan data yang dihasilkan dari pertanyaan dalam kuesioner sudah reliabel. Perceptual mapping digunakan untuk menyajikan persepsi konsumen terhadap buah jeruk lokal dan jeruk impor.

Model Multi Atribut Fishbein digunakan untuk menganalisis sikap konsumen terhadap buah jeruk lokal dan jeruk impor. Model sikap multiatribut Fishbein adalah alat yang sangat berguna untuk mempelajari proses pembentukan, memperkirakan, dan menganalisis sikap konsumen terhadap atribut produk (Simamora 2002).

Menurut Engel et al. (1995), model multi atribut Fishbein menggambarkan sikap konsumen terhadap sebuah produk atau merek sebuah produk yang ditentukan oleh dua hal, yaitu kepercayaan terhadap atribut yang dimiliki produk atau merek (komponen $b_{i}$ ) dan evaluasi pentingnya atribut dari produk tersebut (komponen $\mathrm{e}_{\mathrm{i}}$ ). Model ini digambarkan oleh formula sebagai berikut.

$$
A_{o}=\sum_{i=1}^{n} b i . e i
$$

Keterangan:

Ao $=$ Sikap terhadap objek

$\mathrm{b}_{\mathrm{i}}=$ Kekuatan kepercayaan bahwa objek memiliki atribut $\mathrm{i}$

$\mathrm{e}_{\mathrm{i}}=$ Evaluasi kepentingan terhadap atribut $\mathrm{i}$

$\mathrm{n}=$ Jumlah atribut yang dimiliki oleh objek

\section{HASIL DAN PEMBAHASAN}

\section{Karakteristik Umum Responden}

Mayoritas responden buah jeruk di pasar modern Kota Bogor adalah perempuan, berada pada kelompok usia 27-34 tahun, berstatus sudah menikah, berprofesi sebagai ibu rumah tangga dengan pendidikan akhir Sarjana (S1). Hal ini menunjukkan bahwa perempuan pada umumnya lebih berperan dalam belanja rumah tangga dan pengambilan keputusan pembelian kebutuhan sehari-hari, termasuk buah yang dikonsumsi.

Selain itu mereka berasal dari keluarga yang berukuran relatif kecil (3-4 orang) dan tingkat pendapatan di atas Rp 4.000.000 setiap bulan. Hal ini menunjukkan konsumsi buah jeruk memiliki peran penting dalam sebuah keluarga dan responden termasuk ke dalam golongan menengah ke atas dengan penghasilan yang tinggi serta tingkat pendidikan yang baik.

\section{Proses Keputusan Pembelian}

Motivasi responden dalam mengkonsumsi buah jeruk yaitu sebagai sumber vitamin yang bermanfaat menjaga kesehatan, dan merasa ada yang kurang jika tidak mengkonsumsinya. Informasi mengenai buah jeruk yang dikonsumsinya diperoleh dari keluarga dan penjual. Sumber yang mempengaruhi 
keputusan pembelian didominasi oleh keluarga (istri) dan diri sendiri.

Atribut rasa dan penampilan menjadi pertimbangan responden dalam membeli buah jeruk. Responden membeli buah jeruk di pasar modern secara terencana dengan alasan produk bermutu.

Toko buah menjadi lokasi pembelian buah jeruk selain di pasar modern. Mayoritas responden mengkonsumsi buah jeruk dengan frekuensi pembelian 1-2 kali dalam sebulan dan membeli sebanyak 3-4 kilogram.

Responden akan membeli buah jeruk di tempat lain jika buah jeruk tidak tersedia di pasar modern, responden merasa tidak keberatan apabila harga buah jeruk mengalami kenaikan, responden merasa puas membeli buah jeruk di pasar modern, berkeinginan melakukan pembelian ulang, dan setuju untuk merekomendasikan buah jeruk.

\section{Penilaian Komponen Evaluasi (Tingkat Kepentingan)}

Hasil penilaian responden terhadap tingkat kepentingan pada Tabel 1 menunjukkan bahwa responden menilai dua dari dua belas atribut buah jeruk adalah sangat penting yaitu atribut rasa dan kondisi kesegaran. Hal ini menunjukkan bahwa responden akan mempertimbangkan atribut rasa dan kondisi kesegaran sebagai atribut terpenting dalam memilih dan membeli buah jeruk.

Tujuh atribut buah jeruk yang dinilai penting oleh responden yaitu kandungan air, tingkat kematangan, kebersihan kulit, tekstur daging buah, kemudahan memperoleh, harga, dan warna kulit. Tiga atribut lainnya yaitu atribut jumlah biji, ukuran buah jeruk, dan promosi penjualan dinilai biasa atau netral oleh responden.

Tabel 1. Nilai Kepentingan $\left(e_{i}\right)$ dan Kategori Tingkat Kepentingan Atribut Buah Jeruk

\begin{tabular}{lclc}
\hline \multicolumn{1}{c}{ Atribut } & Kepentingan $\left(\mathbf{e}_{\mathbf{i}}\right)$ & \multicolumn{1}{c}{ Kategori } & Urutan $\left(\mathbf{e}_{\mathbf{i}}\right)$ \\
\hline Rasa & 4,63 & Sangat penting & I \\
Kondisi kesegaran & 4,42 & Sangat penting & II \\
Kandungan air & 4,13 & Penting & III \\
Tingkat kematangan & 4,11 & Penting & IV \\
Kebersihan kulit & 3,80 & Penting & V \\
Tekstur daging buah & 3,78 & Penting & VI \\
Kemudahan memperoleh & 3,61 & Penting & VII \\
Harga & 3,56 & Penting & VIII \\
Warna kulit & 3,55 & Penting & IX \\
Jumlah biji & 3,24 & Biasa & X \\
Ukuran & 3,23 & Biasa & XI \\
Promosi penjualan & 3,04 & Biasa & XII \\
\hline
\end{tabular}




\section{Penilaian Komponen Kepercayaan} Tingkat Pelaksanaan

Hasil penilaian responden terhadap kepercayaan tingkat pelaksanaan atribut buah jeruk lokal dapat dilihat pada Tabel 2 . Secara umum responden percaya bahwa buah jeruk lokal yang dijumpai di pasar modern sudah baik. Tekstur daging buah dan kandungan air dinilai konsumen merupakan atribut buah jeruk lokal yang terbaik. Harga dan promosi penjualan buah jeruk lokal merupakan atribut yang belum mendapat kepercayaan baik oleh responden.

Hasil penilaian responden terhadap kepercayaan tingkat pelaksanaan atribut buah jeruk impor dapat dilihat pada Tabel 3.

Tabel 2. Nilai Kepercayaan $\left(b_{i}\right)$ dan Kategori Tingkat Pelaksanaan Atribut Buah Jeruk Lokal

\begin{tabular}{lcc}
\hline \multirow{2}{*}{\multicolumn{1}{c}{ Atribut }} & \multicolumn{2}{c}{ Buah Jeruk Lokal } \\
\cline { 2 - 3 } & Kepercayaan $\left(\mathbf{b}_{\mathbf{i}}\right)$ & Kategori \\
\hline Harga & 2,66 & Biasa \\
Rasa & 4,06 & Baik \\
Kemudahan memperoleh & 3,58 & Baik \\
Kandungan air & 4,09 & Baik \\
Warna kulit & 3,60 & Baik \\
Ukuran & 3,32 & Biasa \\
Kebersihan kulit & 3,65 & Baik \\
Kondisi kesegaran & 3,79 & Baik \\
Tingkat kematangan & 3,84 & Baik \\
Tekstur daging buah & 4,14 & Baik \\
Jumlah biji & 3,14 & Biasa \\
Promosi Penjualan & 3,09 & Biasa \\
\hline
\end{tabular}

Tabel 3. Nilai Kepercayaan $\left(b_{i}\right)$ dan Kategori Tingkat Pelaksanaan Atribut Buah Jeruk Impor

\begin{tabular}{lcc}
\hline \multirow{2}{*}{\multicolumn{1}{c}{ Atribut }} & \multicolumn{2}{c}{ Buah Jeruk Impor } \\
\cline { 2 - 3 } & Kepercayaan $\left(\mathbf{b}_{\mathbf{i}}\right)$ & Kategori \\
\hline Harga & 2,39 & Buruk \\
Rasa & 3,45 & Biasa \\
Kemudahan memperoleh & 2,66 & Biasa \\
Kandungan air & 3,58 & Baik \\
Warna kulit & 4,58 & Sangat baik \\
Ukuran & 3,29 & Biasa \\
Kebersihan kulit & 3,74 & Baik \\
Kondisi kesegaran & 3,62 & Baik \\
Tingkat kematangan & 3,69 & Baik \\
Tekstur daging buah & 3,78 & Baik \\
Jumlah biji & 3,38 & Biasa \\
Promosi Penjualan & 3,61 & Baik \\
\hline
\end{tabular}


Secara umum responden percaya bahwa buah jeruk impor yang biasa dijumpai di pasar modern sudah baik. Penampilan buah jeruk impor yang ditunjukkan oleh atribut warna kulit dan kebersihan kulit dipercaya sudah baik oleh konsumen. Tekstur daging buah dan promosi penjualan juga dipercaya sudah baik oleh responden, akan tetapi atribut harga buah jeruk impor belum mendapat kepercayaan yang baik oleh responden.

\section{Sikap Responden terhadap Atribut Buah Jeruk Lokal dan Buah Jeruk Impor}

Berdasarkan data pada Tabel 4, diketahui bahwa atribut buah jeruk lokal yang memiliki nilai sikap tinggi atau baik adalah rasa, kandungan air, kondisi ke- segaran, tingkat kematangan, dan tekstur daging buah.

Hal ini menunjukkan bahwa kelima atribut tersebut merupakan atribut yang disukai oleh responden untuk buah jeruk lokal. Sedangkan sikap yang memiliki nilai terendah untuk buah jeruk lokal adalah harga.

Berdasarkan data pada Tabel 5, diketahui bahwa atribut buah jeruk impor yang memiliki nilai sikap tinggi atau baik adalah rasa, warna kulit, dan kondisi kesegaran.

Hal ini menunjukkan bahwa ketiga atribut tersebut merupakan atribut yang disukai responden untuk buah jeruk impor. Tidak berbeda dengan atribut harga di buah jeruk lokal, atribut harga pada buah jeruk impor juga memiliki nilai sikap terendah.

\section{Tabel 4. Hasil Analisis Sikap terhadap Atribut Buah Jeruk Lokal}

\begin{tabular}{|c|c|c|c|}
\hline \multirow{2}{*}{ Atribut } & \multirow{2}{*}{$\left(\mathbf{e}_{\mathrm{i}}\right)$} & \multicolumn{2}{|c|}{ Buah Jeruk Lokal } \\
\hline & & $\left(\mathbf{b}_{\mathrm{i}}\right)$ & $\operatorname{Ao}\left(e_{i} \cdot b_{i}\right)$ \\
\hline Harga & 3,56 & 2,66 & 9,47 \\
\hline Rasa & 4,63 & 4,06 & 18,80 \\
\hline Kemudahan memperoleh & 3,61 & 3,58 & 12,92 \\
\hline Kandungan air & 4,13 & 4,09 & 16,89 \\
\hline Warna kulit & 3,55 & 3,60 & 12,78 \\
\hline Ukuran & 3,23 & 3,32 & 10,72 \\
\hline Kebersihan kulit & 3,80 & 3,65 & 13,87 \\
\hline Kondisi kesegaran & 4,42 & 3,79 & 16,75 \\
\hline Tingkat kematangan & 4,11 & 3,84 & 15,78 \\
\hline Tekstur daging buah & 3,78 & 4,14 & 15,65 \\
\hline Jumlah biji & 3,24 & 3,14 & 10,17 \\
\hline Promosi Penjualan & 3,04 & 3,09 & 9,39 \\
\hline$\sum\left(e_{i} \cdot b_{i}\right)$ & & & 163,21 \\
\hline
\end{tabular}


Tabel 5. Hasil Analisis Sikap terhadap Atribut Buah Jeruk Impor

\begin{tabular}{|c|c|c|c|}
\hline \multirow{2}{*}{ Atribut } & \multirow{2}{*}{$\left(\mathbf{e}_{i}\right)$} & \multicolumn{2}{|c|}{ Buah Jeruk Impor } \\
\hline & & $\left(\mathbf{b}_{\mathbf{i}}\right)$ & $\operatorname{Ao}\left(e_{i} \cdot b_{i}\right)$ \\
\hline Harga & 3,56 & 2,39 & 8,51 \\
\hline Rasa & 4,63 & 3,45 & 15,97 \\
\hline Kemudahan memperoleh & 3,61 & 2,66 & 9,60 \\
\hline Kandungan air & 4,13 & 3,58 & 14,79 \\
\hline Warna kulit & 3,55 & 4,58 & 16,26 \\
\hline Ukuran & 3,23 & 3,29 & 10,63 \\
\hline Kebersihan kulit & 3,80 & 3,74 & 14,21 \\
\hline Kondisi kesegaran & 4,42 & 3,62 & 16,00 \\
\hline Tingkat kematangan & 4,11 & 3,69 & 15,17 \\
\hline Tekstur daging buah & 3,78 & 3,78 & 14,29 \\
\hline Jumlah biji & 3,24 & 3,38 & 10,95 \\
\hline Promosi Penjualan & 3,04 & 3,61 & 10,97 \\
\hline$\sum\left(\mathrm{e}_{\mathrm{i}} \cdot \mathrm{b}_{\mathrm{i}}\right)$ & & & 157,35 \\
\hline
\end{tabular}

Keterangan:

$\mathrm{e}_{\mathrm{i}}=$ Evaluasi kepentingan

$\mathrm{b}_{\mathrm{i}}=$ Kepercayaan

Ketika membandingkan nilai sikap antara buah jeruk lokal dan buah jeruk impor, dapat diketahui bahwa buah jeruk impor lebih unggul pada keempat atribut, yaitu atribut warna kulit, kebersihan kulit, jumlah biji, dan promosi penjualan. Hasil ini sesuai dengan hasil nilai kepercayaan buah jeruk impor yang juga menunjukkan keunggulan pada keempat atribut tersebut.

Meskipun demikian, ada beberapa atribut buah jeruk lokal yang memiliki nilai sikap lebih tinggi dibandingkan dengan buah jeruk impor yaitu harga, rasa, kemudahan memperoleh, ukuran, kondisi kesegaran, kandungan air, tingkat kematangan, dan tekstur daging buah.

Secara keseluruhan total nilai sikap (Ao) untuk buah jeruk lokal sebesar 163,21 poin. Sedangkan buah jeruk impor memiliki total nilai sikap sebesar 157,35 poin. Dengan demikian, secara keseluruhan responden memiliki nilai sikap yang lebih tinggi terhadap buah jeruk lokal dibanding- kan buah jeruk impor. Hal ini dapat terjadi karena responden menilai secara keseluruhan atribut buah jeruk lokal lebih baik dari pada atribut buah jeruk impor.

\section{Pemetaan Persepsi}

Peta persepsi responden terhadap kepercayaan tingkat pelaksanaan buah jeruk lokal dan jeruk impor dapat dilihat pada Gambar 1. Berdasarkan kepercayaan tingkat pelaksanaannya, persepsi responden terhadap buah jeruk lokal lebih baik dibandingkan buah jeruk impor dengan atribut yang dipersepsikan lebih unggul yaitu atribut harga, rasa, kemudahan memperoleh, ukuran, kandungan air, kondisi kesegaran, tingkat kematangan, dan tekstur daging buah.

Sedangkan kepercayaan tingkat pelaksanaan atribut buah jeruk impor dipersepsikan lebih unggul pada atribut kebersihan kulit, warna kulit, jumlah biji, dan promosi penjualan. 


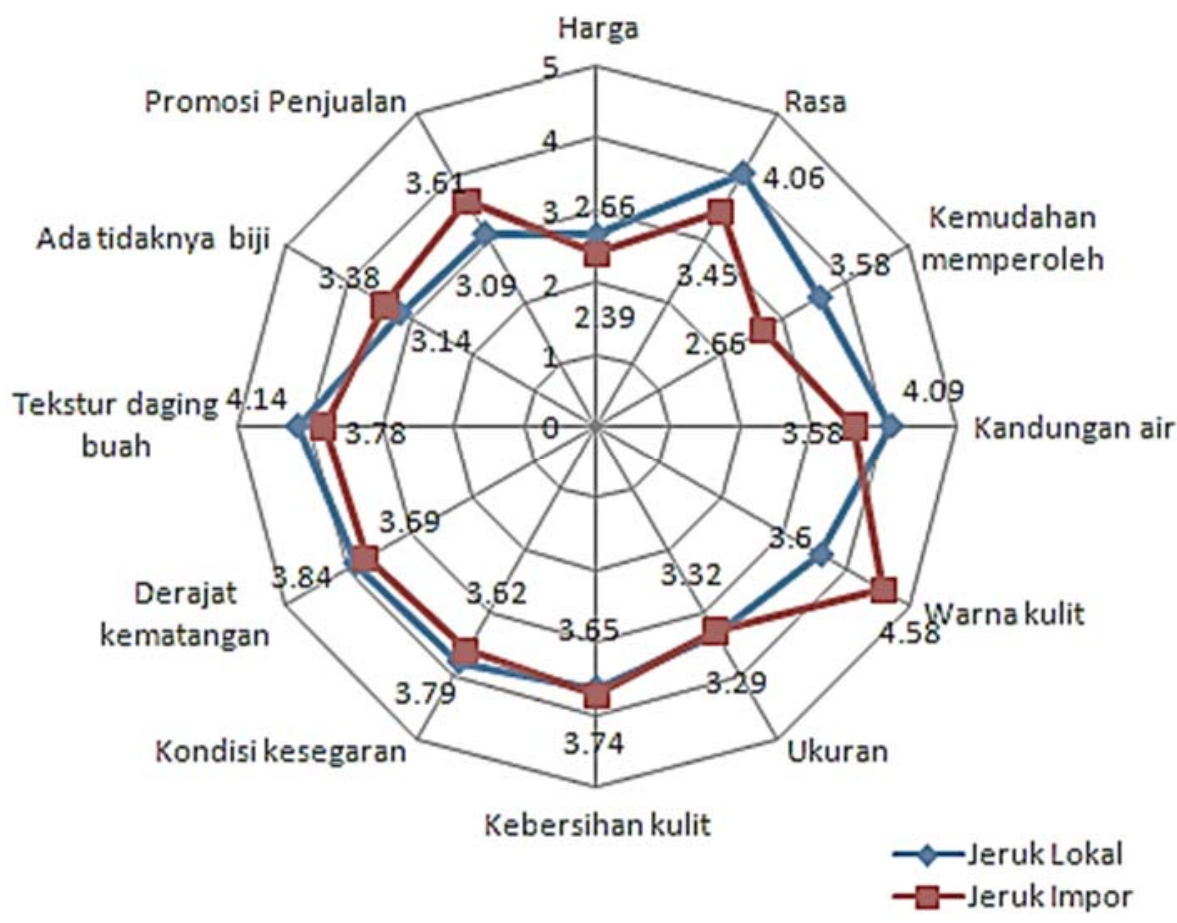

\section{Gambar 1. Peta Persepsi Responden terhadap Kepercayaan Tingkat Pelaksanaan Buah Jeruk Lokal dan Buah Jeruk Impor}

Hal ini menunjukkan, kepercayaan tingkat pelaksanaan atribut buah jeruk lokal pada atribut kebersihan kulit, warna kulit, jumlah biji, dan promosi penjualan dipersepsikan kurang baik.

Dilihat dari kepercayaan tingkat pelaksanaan atribut, buah jeruk lokal memiliki atribut terunggul yaitu tekstur daging buah dan atribut terburuk yaitu promosi penjualan. Sedangkan buah jeruk impor memiliki atribut terunggul yaitu warna kulit dan atribut terburuk yaitu harga.

\section{Implikasi Manajerial dalam}

Peningkatan Sikap Konsumen terhadap Buah Jeruk Lokal

Buah jeruk lokal memiliki keunggulan terhadap atribut harga, rasa, kemudahan memperoleh, kandungan air, ukuran, kondisi kesegaran, tingkat kematangan, dan tekstur daging buah. Pasar modern selaku pemasar buah jeruk lokal harus dapat mempertahankannya dengan konsisten memenuhi standar mutu buah jeruk lokal yang telah ditetapkan oleh pasar modern. 
Kelemahan buah jeruk lokal terletak pada penampilannya yang kurang menarik, yaitu atribut kebersihan kulit dan warna kulit. Dibutuhkan kerjasama yang baik di antara petani sebagai produsen buah jeruk dan pelaku agribisnis lainnya, karena buah jeruk yang distribusinya terhambat, terlalu lama disimpan dalam gudang dan mendapat perlakuan pengemasan serta penyimpanan yang kurang baik akan mempengaruhi kualitas dari buah jeruk tersebut ketika dijual.

Konsumen di pasar modern akan tetap membeli buah jeruk lokal apabila terjadi kenaikan harga selama harga yang dibayarkan masih sesuai dengan manfaat yang mereka peroleh dari mengkonsumsi buah jeruk lokal. Hal ini terkait konsumen pasar modern yang termasuk golongan menenegah ke atas dengan pendapatan tinggi dan pendidikan baik. Keterjangkauan harga jeruk bagi konsumen, membuat pemasar (pasar modern) perlu menerapkan harga yang rasional bagi konsumen agar konsumen tetap membeli buah jeruk lokal.

Pasar modern perlu memperhatikan ketersediaan buah jeruk lokal karena akan menghindarkan kemungkinan responden beralih membeli buah lainnya termasuk buah jeruk impor. Display buah jeruk lokal juga perlu diperhatikan oleh pasar modern agar dapat menarik perhatian konsumen untuk membeli. Hal ini terkait dengan dominasi kaum perempuan dalam melakukan pembelian buah jeruk.

Berdasarkan hasil penilaian responden terhadap tingkat kepercayaan diketahui bahwa kinerja atribut iklan atau promosi penjualan pada buah jeruk impor lebih baik dibandingkan dengan buah jeruk lokal. Hal ini menunjukkan bahwa, responden menilai pasar modern cenderung lebih sering melakukan promosi penjualan pada buah jeruk impor. Oleh karena itu, pasar modern dapat menambah frekuensi promosi untuk buah jeruk lokal melalui katalog harga, iklan di media cetak maupun media elektronik serta memasang display buah jeruk lokal dalam ukuran yang besar agar dapat menarik perhatian konsumen untuk membeli buah jeruk lokal.

\section{KESIMPULAN DAN SARAN}

\section{Kesimpulan}

1. Karakteristik konsumen buah jeruk di pasar modern Kota Bogor yaitu berjenis kelamin wanita, berusia 27-34 tahun, pendidikan akhir Sarjana (S1), berstatus sudah menikah, berprofesi sebagai ibu rumah tangga, memiliki jumlah anggota keluarga 3-4 orang, serta memiliki pendapatan setiap bulan di atas $\mathrm{Rp}$ 4.000.000.

2. Proses keputusan pembelian responden dilakukan sesuai dengan teori Engel et al. (1995) yang terdiri atas lima tahapan, yaitu tahap pengenalan kebutuhan, pencarian informasi, evaluasi alternatif, proses pembelian, dan perilaku pasca pembelian.

3. Hasil analisis sikap multiatribut Fishbein menunjukkan bahwa responden memiliki nilai sikap yang lebih tinggi pada buah jeruk lokal.

4. Hasil analisis Perceptual Mapping terhadap kepercayaan tingkat pelaksanaan atribut menunjukkan bahwa atribut buah jeruk lokal dipersepsikan lebih unggul pada atribut harga, rasa, kemudahan memperoleh, ukuran, kandungan air, kondisi kesegaran, tingkat kematangan, dan tekstur daging buah. 
5. Atribut buah jeruk impor yang dipersepsikan lebih unggul dibandingkan buah jeruk lokal yaitu atribut kebersihan kulit, warna kulit, jumlah biji, dan promosi penjualan.

\section{Saran}

1. Petani selaku produsen buah jeruk lokal mempunyai kesempatan mengembangkan pasar domestik melalui tindakan mempertahankan, menjaga serta meningkatkan kualitas atribut buah jeruk yang dianggap sangat penting oleh konsumen yaitu rasa dan kondisi kesegaran serta yang dianggap penting yaitu harga, kandungan air, tingkat kematangan, warna kulit, kebersihan kulit, tekstur daging buah, dan kemudahan memperoleh.

2. Petani selaku produsen buah jeruk perlu memperhatikan dan memperbaiki atribut buah jeruk lokal yang dinilai kurang baik oleh konsumen yaitu kebersihan kulit, warna kulit, dan jumlah biji.

3. Pasar modern sebagai pelaku pemasaran buah jeruk perlu memperhatikan kondisi atribut buah jeruk lokal yang dipersepsikan konsumen kurang baik yaitu promosi penjualan.

\section{UCAPAN TERIMA KASIH}

Penulis mengucapkan terima kasih kepada Biro Perencanaan dan Kerjasama Luar Negeri (BPKLN) Kementrian Pendidikan dan Kebudayaan Republik Indonesia yang telah memberikan Beasiswa Unggulan kepada penulis selama menyelesaikan pendidikan S2 di Program Studi Magister Sains Agribisnis, Institut Pertanian Bogor.

\section{DAFTAR PUSTAKA}

[BPS] Badan Pusat Statistik. 2009. Survei Sosial Ekonomi Nasional (SUSENAS) 2009. Pengeluaran untuk Konsumsi Penduduk Indonesia. Buku 1. Badan Pusat Statistik. Jakarta.

[BPS] Badan Pusat Statistik Kota Bogor. 2012. Kota Bogor dalam Angka. BPS Kota Bogor. Bogor.

[Ditjenhor] Direktorat Jenderal Hortikultura. 2013. Produksi Buah Jeruk Tahun 2012. Departemen Pertanian. Direktorat Jenderal Hortikultura. Jakarta.

. 2013. Nilai Impor Buah Jeruk Tahun

2012. Departemen Pertanian.

Direktorat Jenderal Hortikultura. Jakarta.

Engel JF, Roger DB, Paul WM. 1995. Perilaku Konsumen. Ed ke-6. Jilid 2. Jakarta.

Kartika DN, Evita SH, Rudi H. 2010. Analisis Perilaku Konsumen Buah di Pasar Tradisional dan Pasar Modern Kecamatan Kaliwates Kabupaten Jember. Jurnal SEP. 4(1):24-36.

Kementrian Pertanian. 2013. Volume Impor Buah Jeruk Tahun 2012. Kementrian Pertanian. Jakarta.

Kotler P, Gary A. 2008. Prinsip-Prinsip Pemasaran. Ed-12. Jilid 1. Erlangga. Jakarta.

Poerwanto R, Susanto S, S Setyati. 2002. Pengembangan Jeruk Unggulan Indonesia. Makalah Semiloka Nasional Pengembangan Jeruk Unggulan. Bogor. 
Rangkuti F. 2003. Measuring Customer Satisfaction, Teknik Mengukur dan Strategi Meningkatkan Kepuasan Pelanggan. Gramedia Pustaka Utama. Jakarta.

. 2005. Riset Pemasaran. Gramedia Pustaka Utama. Jakarta.

Simamora. 2002. Panduan Riset Perilaku Konsumen. PT Gramedia Pustaka Utama. Jakarta.

Widodo. 2005. Sikap Konsumen terhadap Buah Impor di Kota Yogyakarta. Universitas Muhammadiyah Yogyakarta. Yogyakarta.

2008. Sikap Konsumen terhadap Jeruk dan Pisang Lokal Segar di Kota Yogyakarta. Universitas Muhammadiyah Yogyakarta. Yogyakarta.

\section{BIODATA LENGKAP PENULIS}

Sarah Nur Nafisah. Penulis lahir di Pontianak pada tanggal 18 Mei 1992 sebagai anak kedua pasangan Budi Joyo Santoso dan Sri Pujiyatiningsih. Penulis lulus dari SMA Negeri 26 Jakarta pada tahun 2009 dan lulus seleksi masuk Institut Pertanian Bogor (IPB) melalui jalur Ujian Talenta Mandiri IPB di Departemen Agribisnis, Fakultas Ekonomi dan Manajemen. Penulis merupakan mahasiswa yang mengikuti program mayor-minor dengan mayor Departemen Agribisnis dan minor Komunikasi. Saat ini penulis terdaftar sebagai mahasiswa Fast Track program Magister Sains Agribisnis, Institut
Pertanian Bogor melalui Beasiswa Unggulan Biro Perencanaan dan Kerjasama Luar Negeri (BPKLN) Kementrian Pendidikan dan Kebudayaan Republik Indonesia.

Suharno. Penulis lahir di Rembang pada tanggal 10 Juni 1961. Penulis menyelesaikan pendidikan Sarjana (S-1) pada tahun 1985 di Institut Pertanian Bogor, jurusan Ilmu-Ilmu Sosial Ekonomi Pertanian. Penulis menyelesaikan pendidikan Magister (S-2) pada tahun 1992 di State University of Ghent, Belgium. Penulis menyelesaikan pendidikan Doktor (S-3) pada tahun 2002 di Georg-August University of Gottingen, Germany. Saat ini penulis aktif mengajar sebagai dosen pada program pendidikan sarjana dan pascasarjana di Institut Pertanian Bogor.

Netti Tinaprilla. Penulis lahir di Bogor pada tanggal 10 April 1969. Penulis menyelesaikan pendidikan Sarjana (S-1) pada tahun 1992 di Institut Pertanian Bogor, Jurusan Sosial Ekonomi Pertanian. Sejak tahun 1992, penulis aktif mengajar di Institut Pertanian Bogor dan menyelesaikan pendidikan S-2 pada tahun 1997 di Institut Pertanian Bogor. Penulis menyelesaikan pendidikan Doktor (S-3) pada tahun 2012 di Institut Pertanian Bogor. Saat ini penulis aktif mengajar sebagai dosen pada program pendidikan sarjana dan pascasarjana di Institut Pertanian Bogor. 
Sarah Nur Nafisah, Suharno dan Netti Tinaprilla 